\title{
CIVIC VALUES DAN ISLAM: \\ Islam Awal dan Potret Pembangunan Civil Society
}

\author{
Alim Roswantoro \\ Fakultas Ushuluddin UIN Sunan Kalijaga Yogyakarta
}

\begin{abstract}
Civic Values dewasa ini telah menggejala di berbagai negara suatu cita-cita sosial yang dikemas dalam bentuke pendidikan kewargaan atau civic education yang memiliki arti yang sangat penting dan strategis bagi kelangsungan kehidupan berbangsa dan bernegara. Jika dianalisis dari paradigma kultur mana kedua masyarakat itu lahir dan tumbuh, perbedaan asasiah antara Masyarakat Madani dan civil society akan tampak. Jika kembali kepada kultur para filosof sosial Barat abad ketujub belas di mana wacana civil society itu mulai digulirkan, maka civil society di Barat labir sebagai buah modernitas yang mengambil akarnya pada gerakan budaya Renaissance. Budaya ini merupakan gerakan yang memarginalkan gagasan tentang Tuban. Buah masyarakat dari gerakan budaya semacam ini adalah masyarakat sekuler, yang menurut Clavel, di dalamnya posisi Tuban telah menjadi gagasan yang tertindas sejak lebih dari tiga abad yang lalu.
\end{abstract}

Kata kunci: Islam, civic values, civil society.

\section{Pendahuluan}

Dewasa ini telah menggejala di berbagai negara suatu cita-cita sosial yang dikemas dalam bentuk pendidikan kewargaan atau civic education yang memiliki arti sangat penting dan strategis bagi kelangsungan kehidupan berbangsa dan bernegara. Civic Education di Amerika Serikat diajarkan secara integral dalam State Ideology, di Inggris disebut dengan Citizenship Education, di Philipina Civic and Human Rights Education, di Kuwait Tarbiyah al-Wathoniyyah, di Maroko Talimiyyah al-mawadi'ah, dan lain sebagainya. Di Indonesia sekarang mengajarkan matakuliah Pancasila dan Pendidikan Kewarganegaraan atau Pendidikan Kewargaan. Fenomena ini mengindikasikan bahwa Civic Values telah menjadi global need dan dianggap sebagai pilar dasar penegak nilai-nilai kemanusiaan di muka bumi ini. 
Civic Values dalam versi Indonesia biasanya disebut dengan nilai-nilai kewarganegaraan, tetapi ada juga menyebutnya lebih umum nilai-nilai kewargaan, tanpa menyebut negara. Tulisan ini lebih memilih penyebutan yang kedua. Penyebutan yang pertama terkesan lebih sempit karena hanya berbicara tentang kewargaan seseorang dalam suatu negara tertentu, sedangkan yang kedua mengonotasikan pengertian kewargaan suatu negara dan sekaligus kewargaan mondial seseorang, bahkan bisa lebih luas dari sekedar dua kewargaan itu, orang dari segi kewargaan bisa berwajah banyak identitas atau multi identitas. Manusia dengan multi identitas artinya bahwa dia adalah warga suatu keluarga, warga suatu kampung, warga suatu kota, warga suatu marga, warga suatu agama, warga suatu budaya, warga suatu suku, dan lain sebagainya.

Berbicara tentang civic values atau nilai-nilai kewargaan berarti berbicara tentang kehidupan manusia sebagai anggota masyarakat. Jika tidak menginginkan suatu kehidupan, maka manusia tidak perlu berbicara tentang nilai-nilai kewargaan. Dengan kata lain, ketika berbicara tentang nilai-nilai kewargaan, berarti juga berbicara mengenai kehidupan dalam ruang yang lebih sempit, yaitu kehidupan tentang warga: apa artinya menjadi warga suatu masyarakat, bagaimana seharusnya seorang warga bersikap dan berperilaku di tengah-tengah komunitasnya, mengapa setiap orang mesti menjadi warga suatu masyarakat tertentu dan bagaimana hubungannya dengan orang-orang lain yang menjadi warga dari masyarakat-masyarakat selainnya. ${ }^{1}$

Civic values secara etimologis berasal dari kata value yang artinya nilai, dan civic bisa berarti warga atau warga negara. Secara istilah, civic values adalah "the principles that guide both the government and the public life of the people." Yang berkembang dan dikembangkan di Amerika serikat ada delapan nilai kewargaan atau kewarganegaraan yakni, respect, love, honesty, fairness, charity, hard work, tolerance, dan freedom. Pertama sikap saling menghargai, yang kedua saling mencintai sesama manusia, yang ketiga kejujuran atas bersikap apa adanya terhadap sesama warga, yang keempat kesportifan dalam bergaul

${ }^{1}$ Alim Roswantoro, “Civic Values: Membangun Visi Warga dan Kewargaan Menuju Masyarakat Madani, Perspektif Filsafat Sosial" dalam Jurnal Pemikiran Filsafat dan Pemikiran Keislaman Refleksi, Vol. 5 No. 2 Juli 2005: h. 101.

${ }^{2}$ Lihat Machasin, "Respon Pesantren terhadap Civic Values, makalah dipresentasikan dalam Public Hearing Pengembangan Pesantren, Hotel Sahid Yogyakarta, 31 Mei - 1 Juni 2005: h. 2-3. 
di antara sesama warga, yang kelima kemurahhatian atau selalu ringan membantu warga yang lemah dan memerlukan bantuan, yang keenam kerja keras atau mendapatkan kemakmuran dengan bekerja keras menurut normanorma yang berlaku, yang ketujuh toleransi atau menahan diri terhadap perbedaan, dan yang kedelapan kebebasan. ${ }^{3}$ Sedangkan di Australia dikembangkan sepuluh prinsip civic values yang memiliki pengertian yang hampir sama dengan tradisi di Amerika tersebut, yaitu tolerance and understanding atau saling menenggang perbedaan dan saling memahami, respect atau saling menghargai dan menghormati, responsibility atau tanggung jawab atas perbuatan yang dilakukan, social justice ata perlakuan yang adil atas setiap warga secara sosial, excellence atau berusaha mendapatkan sesuatu yang berharga dan terpuji secara individual maupun kelompok, care atau peduli pada orang dan juga diri sendiri, inclusion and trust atau merasa sebagai bagian dari dan memasukkan orang di dalam keseluruhan masyarakat dengan secara aktif mendengarkan pikiran dan perasaan orang lain dan menciptakan iklim saling percaya, bonesty atau kejujuran, freedom atau kebebasan, dan being ethical atau bertindak sesuai aturan. ${ }^{4}$

Dalam kehidupan sosial politik masyarakat manusia, civic values memang menjadi pilar penguatan civil society. Civil society bisa dicirikan oleh ruang publik yang bebas, demokratis, pluralis, toleran, keadilan sosial, dan berkeadaban. ${ }^{5}$ Syafi'i Ma'arif menggarisbawahi ada empat ciri civil society, yaitu justice-oriented, egalitarianisme, toleransi dan keterbukaan. ${ }^{6}$ Dari ciriciri ini dapat disimpulkan bahwa tujuan utama dari civil society adalah penjunjungan tinggi nilai-nilai humanitas atau pemanusiaan manusia.

${ }^{3}$ Lihat "civic values" dalam http:uscivicvalues.com/values.html. diakses 1 Oktober 2005.

${ }^{4}$ Lihat "A Draft National Framework for Values Education in Australian Schools", dalam http:/www.curriculum.edu.au. Lihat juga Machasin, Respon Pesantren terbadap Civic Values, makalah dipresentasikan dalam Public Hearing Pengembangan Pesantren, Hote Sahid Yogyakarta, 31 Mei - 1 Juni 2005: h. 2-3.

${ }^{5}$ Ubaidillah dkk, Pendidikan Kewargaan (Civic Education) Demokrasi, HAM, \& Masyarakat Madani, (Jakarta: IAIN Syarif Hidayatullah Press, 2000), h. 147.

'Syafi'i Ma'arif, "Universalisme Nilai-nilai Politik Islam Menuju Masyarakat Madani," Profetika Jurnal Studi Islam, Vol. I, No. 2 Juli 1999: h. 172. 


\section{Sejarah Sekilas: Civic Values dan Dorongan Menggugat Sistem Sosial Otoriter}

Apabila dibuka lembaran-lembaran sejarah hidup manusia dan masyarakatnya, akan didapati keberatan dan keinginan manusia terhadap masyarakatnya. Di beberapa belahan dunia menunjukkan kecenderungan yang sama. Di Yunani kuno, tatanan masyarakat yang penuh mitos berkembang menjadi masyarakat rasional; di Arab, tatanan masyarakat yang jahiliyah pada masa pra Islam berkembang menjadi masyarakat beradab dan manusiawi sejak Islam datang; di Eropa, tatanan masyarakat Abad Pertengahan yang penuh penindasan berkembang menjadi masyarakat yang demokratik; dan demikian juga di Indonesia yang sampai sekarang ini masih berusaha keras menuju masyarakat yang lebih demokratik-komunikatif sebagai reaksi atas masyarakat hegemonik produk Orde Baru.

Di dalam sejarah masyarakat Yunani kuno sebelum muncul para filosof banyak ditemui praktek-praktek hidup yang mitologis dan tidak manusiawi seperti pengorbanan perawan demi stabilitas kelompok masyarakat tertentu, larangan menolong orang yang tenggelam karena keyakinan mereka bahwa yang tenggelam itu memang dimaui oleh roh yang menguasai sungai, dan sebagainya. Tradisi-tradisi ini dinilai Sokrates, filsuf legendaris Yunani, sebagai hanya menguntungkan pihak yang berkuasa dan menindas rakyat sipil. Masyarakat sipil menurutnya hanya menjadi objek kekuasaan dan sama sekali tidak pernah didudukkan sebagai subjek kekuasaan. Dia berpendapat bahwa hal ini mengindikasikan bahwa setiap anggota masyarakat yang tunduk begitu saja pada penguasa sebenarnya tidak pernah mengenal dirinya sendiri sebagai manusia yang memiliki otonomi dan kebebasan diri dan mereka sebenarnya tidak pernah menjadi warga sipil tetapi lebih sebagai budak penguasa. Dari sinilah, dia kemudian berfilsafat tentang manusia sebagai warga suatu city state dan filosofinya kemudian menggerakkan masyarakat sipil bersikap lebih kritis terhadap penguasa. Hal inilah yang akhirnya membawa Sokrates menemui ajalnya di tiang eksekusi penguasa. ${ }^{7}$

${ }^{7}$ Ignacio Ellacuria, "What is the Point of Philosophy", dalam Philosophy and Theology, Vol. 10 No. 1, 1997: h. 3-18. 
Perjuangan dan pengorbanan jiwa Sokrates itu tidak sia-sia, nyawanya telah tiada tetapi pikiran-pikirannya tetap hidup di Yunani bahkan dunia. Karena sejak saat itu rakyat Yunani secara umum mulai menyadari pentingnya suatu tatanan masyarakat di mana warga di beri hak untuk ikut andil dalam mengendalikan masyarakatnya agar hak-hak sipil dihargai dan dijunjung tinggi oleh penguasa. Sepeninggalnya, wacana tentang masyarakat sipil menjadi pembicaraan banyak orang di Yunani terutama di kalangan intelektual. Aristoteles dan Cicero, misalnya, menawarkan suatu konsep tentang masyarakat sipil waktu itu. Aristoteles mengkarakterisir masyarakat sipil dengan masyarakat yang mementingkan warga yang hidup dalam suatu polis atau city state atau komunitas tertentu dengan memegangi prinsip Koinonia Politike, yakni berkumpul bersama atas dasar kesepakatan konstitusional bersama. Sedangkan menurut Cicero, masyarakat sipil adalah masyarakat suatu polis tertentu yang warganya beradab dan mengembangkan aturan-aturan hukum sebagai bentuk ikatan bersama. ${ }^{8}$

Demikian juga, di masyarakat Eropa Abad Tengah, yang sering disebut sebagai masa kegelapan, mentradisikan budaya feodalisme. Budaya ini lebih menguntungkan penguasa dan merugikan yang dikuasai. Dalam budaya ini, penguasa adalah para tuan tanah yang berujung pada raja sebagai penguasa para tuan tanah. Para tuan tanah tunduk pada raja. Mereka harus membayar pajak untuk raja dan militernya. Sebagai gantinya, para tuan tanah memeras kaum papa dan rakyat jelata menjadi budak-budaknya. Merekalah yang menjadi mesin-mesin produksi pertanian dan perkebunan. ${ }^{9}$ Fenomena budaya ini mendapat kritik tajam dari warga sipil masyarakat Eropa. Mereka mengecam budaya ini karena menunjukkan penindasan penguasa atas yang dikuasai dan mengindikasikan suatu perlakuan yang menanggalkan persamaan hak, suatu ketidakadilan dan ketiadaan partisipasi publik atas nasib bersama manusia.

Kritik dan dekonstruksi atas budaya feodal di Eropa ini kemudian menjadi wacana populer di kalangan sipil terutama para intelektual dan filosof. Di antara mereka adalah Thomas Hobbes, John Locke, Jean-Jacques

${ }^{8}$ Lihat Jean L. Cohen and Andrew Arato, Civil Society and Political Theory, (Cambridge: The Mit Press, 1992), 84.; lihat juga Ahmad Baso, Arkeologi Civil Society, (Jakarta: Data Pribadi, 2000), h. 9.

${ }^{9}$ Hansfink, Social Philosophy, (London and New York: Methuen \& Co. Ltd., 1981), h. 6-15. 
Rousseau, Adam Smith, Jeremy Bentham, John Stuart Mill, dan lain sebagainya. Mereka semua pada dasarnya menentang segala bentuk perlakuan yang tidak manusiawi. Hak alamiah setiap manusia adalah hak untuk hidup layak, baik dan aman. Agar setiap orang memiliki peluang untuk memperoleh haknya maka dalam masyarakat harus ada perangkat undang-undang sebagai kontrak sosial di antara para warganya. Kontrak sosial ini didasarkan pada prinsip-prinsip persamaan dan kemanusiaan, bukan kontrak atas dasar kepentingan satu kelompok tertentu. Melalui mereka, prinsip-prinsip demokrasi secara embrional mulai ditradisikan menggantikan budaya feodalisme. ${ }^{10}$

Apabila diteliti secara cermat sejarah masyarakat manusia di berbagai tempat di atas tampak terdapat suatu kecenderungan yang sama, yaitu pelepasan diri dari kungkungan tatanan masyarakat yang otoriter, hegemonik, barbar, dan membungkam kebebasan ruang publik. Ada satu kecenderungan yang sama, ada satu arah yang mirip, semuanya menuju pada tatanan masyarakat yang sehat, yang saleh, yang membuka keterlibatan warga sipil dalam pemberdayaan masyarakat. Kekuasaan yang ingin dibangun adalah kekuasaan yang melibatkan peran dan kekuatan seluruh elemen masyarakat. Mereka tidak menginginkan harus masyarakat yang sempurna, karena ini cenderung utopis, tetapi sebuah masyarakat dengan tatanan yang santun dan manusiawi.

\section{Pluralisme, Demokrasi, Hak Asasi Manusia, dan Gender sebagai Core Values dari Civic Values}

Istilah civic values dalam tulisan ini mengacu pada nilai-nilai keadaban antarmanusia yang satu dengan yang lainnya dengan berbagai perbedaan latar belakang yang menyertainya. Dalam riset ini, dipandang penting menekankan nilai penghormatan atas kemajemukan orang (pluralisme), nilai pelibatan dan partisipasi setiap anggota masyarakat (demokrasi), dan nilai kesetaraan-berkeadilan antara perempuan dan laki-laki (gender).

John Courtney Murray menyatakan bahwa pluralisme adalah kelompok-kelompok orang dengan perbedaan-perbedaan, bahkan

${ }^{10}$ Hansfink, Social Philosopby..., h. 31-33, 40-43, 48-50, dan 65-73. 
pertentangan-pertentangan, pandangan dan identitas yang hidup dalam suatu komunitas sosial-politik, yang karena perbedaan-perbedaan dan pertentangan-pertentangan itu harus dihargai sebagai kekayaan perspektif, maka di dalam komunitas tersebut harus juga terkandung suatu kesepakatan atau konsensus bersama di antara mereka. Menjaga agar kebenaran-kebenaran atau identitas-identitas yang dipegangi orang-orang melalui kesepakatan bersama yang tidak lain berisi suatu kesadaran bahwa ada perbedaan di antara orang-orang dan pentingnya kemauan bersama untuk mempertahankan keyakinan masing-masing tanpa pemaksaan, apalagi kekerasan, tetapi dengan diskusi dan komunikasi, merupakan prinsip dasar dari pluralisme. ${ }^{11}$

Pluralisme dalam pengertian keragaman baik budaya, bahasa, dialek, etnik, tradisi, agama, dan lain sebagainya telah lama menjadi kenyataan hidup manusia. Namun, pluralisme dalam pengertian setiap orang memiliki kesadaran untuk saling menenggang, saling menghargai, dan saling memberi ruang gerak dalam kehidupan publik antar sesama manusia yang berbeda latar budaya, bahasa, dialek, etnik, tradisi, agama, dan lain sebagainya, mungkin belum lama menjadi semangat hidup mansia dalam dua abad terakhir. Pluralisme memayungi banyak nilai kewargaan seperti penghargaan terhadap eksistensi orang lain, toleransi, pemberian kebebasan pada orang lain, dan seterusnya.

Kata "demokrasi" berasal dari dua kata, yaitu demos yang berarti rakyat, dan kratos/cratein yang berarti pemerintahan, sehingga dapat diartikan sebagai pemerintahan rakyat, atau yang lebih kita kenal sebagai pemerintahan dari rakyat, oleh rakyat, dan untuk rakyat. Dalam suatu komunitas apakah itu masyarakat lokal, organisasi, negara, dan masyarakat dunia, suatu kekuasaan untuk menjalankan pemerintahan dan pengaturan urusan-urusan pribadi dan publik semua warganya menjadi sangat diperlukan. Kekuasaan dalam demokrasi adalah kekuasaan yang dihasilkan dari kehendak semua warga komunitas melalui pemberian keterbukaan untuk berpartisipasi memberikan pandangan kepada setiap warga tanpa melihat status dan latar belakangnya, semua diberikan hak untuk mengkomunikasikan kepentingan dan harapan dengan tujuan suatu kesepakatan bersama

\footnotetext{
${ }^{11}$ John Courtney Murray, We Hold These Truth, (New york: Sheed \& Ward, 1960), h. x.
} 
semua warga. Kesepakatan sosial atau kontrak sosial yang dihasilkan merupakan kekuasaan dari semua warga komunitas atau secara umum disebut rakyat. Kekuasaan ini sebagai tujuan dan sekaligus media pemerintahan dari rakyat, oleh rakyat, dan untuk rakyat. Dengan pelibatan dan pembukaan partisipasi semua warga yang dijamin oleh kekuasaan, suatu komunitas, atau organisasi, atau negara dan seterusnya bermaksud menciptakan suatu keadilan sosial, kesejahteraan, keamanan, dan pengondisian kebebasan bagi seluruh warga, tanpa melihat "kotak-kotak" perbedaanperbedaan yang ada.

Perbedaan jenis kelamin (sex differences) itu pada umumnya melahirkan perbedaan gender (gender differences) dalam masyarakat. Perbedaan gender (gender differences) sebenarnya tidaklah menjadi persoalan sepanjang tidak melahirkan ketidakadilan gender (gender inequalities). Namun yang menjadi masalah ternyata perbedaan gender telah melahirkan berbagai ketidakadilan, baik terhadap kaum laki-laki dan terutama terhadap kaum perempuan.

Ketidakadilan gender termanifestasikan dalam berbagai bentuk ketidakadilan, yaitu: pembentukan stereotipe, subordinasi, marginalisasi, beban kerja lebih panjang dan lebih banyak (double burden), kekerasan serta sosialisasi ideologi nilai peran gender. ${ }^{12}$ Manifestasi ketidakadilan gender ini seringkali hadir dalam keyakinan masing-masing orang, keluarga hingga pada tingkat negara dan politik global. Di wilayah inilah sangat perlu dimasukkan perspektif keadilan gender. ${ }^{13}$

Gender sebagai sebuah perspektif untuk memandang kenyataan adalah berbagai asumsi dasar, model, konsep, serta metode yang digunakan untuk mengungkapkan dan menampilkan adanya fenomena gender dalam suatu masyarakat serta berbagai persoalan sosial-budaya yang ditimbulkan-

\footnotetext{
${ }^{12}$ Mansour Fakih, Analisis Gender dan Transformasi Sosial, (Yogyakarta: Pustaka Pelajar, 1999), h.12.

${ }^{13}$ Keadilan gender menggarisbawahi pentingnya kesetaraan sebagai capaian akhir. Keadilan gender menyatakan perlunya perlakuan yang berbeda pada laki-laki dan perempuan, tetapi hal tersebut dilakukan dalam upaya, atau dengan tujuan, untuk mengakhiri ketidaksetaraan, serta untuk mengembangkan kemandirian. Sedangkan kesetaraan gender mengacu pada status, hak-hak dan tanggungjawab yang sama untuk semua perempuan dan laki-laki, serta mengacu pada hak-hak yang seimbang untuk memperoleh perlakuan yang sama. Alim Roswantoro dan Mochamad Sodik, Nilai-nilai Masyarakat Madani dalam Pemberdayaan Ekonomi, (Yogykarta: Puskadiabuma dan The Asia Foundation, 2008), 91
} 
nya. Dengan menggunakan perspektif ini, kepekaan kita terhadap fenomena ketidakadilan gender akan menjadi lebih kuat. Kita dapat memberi perhatian pada pola-pola interaksi, relasi dan pemisahan sosial antara laki-laki dan perempuan, serta berbagai macam implikasinya. ${ }^{14}$

Perspektif keadilan gender ini seringkali digunakan untuk pembelaan terhadap kaum perempuan yang diperlakukan secara tidak adil. Fenomena ketidakadilan terhadap perempuan dapat terjadi di mana pun: di sektor publik maupun domestik, di ruang sosial maupun privat. Di ruang-ruang itulah perempuan didefinisikan, dihadirkan dan diperlakukan. Jika fenomena itu meliputi basis kesadaran dan bangunan nilai yang kompleks, maka dimensi agama merupakan bagian yang amat penting.

Dalam masyarakat muslim seperti Indonesia, Islam menjadi kerangka normatif bangsa karena pemeluknya yang mayoriras. Oleh karena itu, konstruksi gender dan konstruksi seksualitas banyak dipengaruhi oleh pemikiran dan pemahaman agama yang berkembang di masyarakat. Terlebih lagi, masuknya Islam ke kawasan Nusantara bersifat damai dan gradual yang memungkinkan terjadinya proses silang budaya antara Islam dan budaya lokal yang pada gilirannya membentuk pola pemahaman keagamaan yang khas. ${ }^{15}$ Karena pola pemahaman keagamaan itu melibatkan dimensi kreatif manusia, maka tidak ada yang "tabu" dalam pemahaman keagamaan untuk ditelaah ulang, karena siapa tahu jika yang selama ini kita anggap sebagai kebenaran dogma agama itu — dalam istilah Peter L. Berger dan Luckmann — adalah sesuatu yang bersifat socially constructed. ${ }^{16}$

Nilai-nilai pluralisme, demokrasi, dan gender sebagai inti dari civic values memiliki tiga signifikansi, yaitu, pertama, pengangkatan ketiga nilai tersebut yang berkembang secara umum mendorong terjadinya komunikasi antar warga dalam suatu ranah publik yang bertujuan saling memberdayakan

\footnotetext{
${ }^{14}$ Heddy Shri Ahimsa-Putra, "Gender dan Pemaknaannya: Sebuah Ulasan Singkat", Makalah Disampaikan dalam Workshop "Sensivitas Gender dalam Manajemen”, PSW IAIN Sunan Kalijaga, 28 September 2000, h. 7-8.

${ }^{15}$ Siti Ruhaini Dz., "Pengantar", dalam Islam dan Konstruksi Seksualitas, (Yogyakarta: PSW IAIN- The Ford Foundation-Pustaka Pelajar, 2002), h. vii.

${ }^{16}$ Persoalan ini diulas oleh Peter L. Berger dan Thomas Luckmann, dalam buku The Social Construction of Reality, a Treatise in The Sociology of Knowledge, (New York: Double Day \& Company, 1966); Berger, The Secred Canopy: Elements of a Sociological Theory of Religion, (New York: Anchors Books, 1969).
} 
untuk kemandirian. Kedua, ketiga nilai tersebut dipahami sebagai modal sosial-budaya-ekonomi-politik bagi kehidupan bersama masyarakat manusia agar merasa tetapi terlindungi meski mereka berbeda pikiran, kepentingan, pekerjaan, etnik, bahasan, tradisi, budaya, agama, dan lain sebagainya. Ketiga, karena pentingnya ketiganya sebagai modal sosialbudaya-ekonomi-politik bagi kehidupan bersama masyarakat manusia dalam proses pemberdayaan kesehatan mentalitas moral sosial-politik hidup, muncullah kesadaran mengenai ketiga nilai tersebut sehingga lahir mentalitas yang inklusif, yang mendorong partisipasi setiap orang, dan yang mengambangkan kemitraan dan kerjasama antara perempuan dan laki-laki.

\section{Islam Awal dan Praktek Penguatan Civic Values Membangun Civil Society}

Islam memiliki makna yang eksplisit sebagai visi dan misinya, yakni keselamatan dan perdamaian. Islam adalah agama yang mengajarkan bahwa satu-satunya keutamaan hidup yang paling puncak adalah hanya tunduk, patuh, taat, dan pasrah pada kemauan dan peraturan Tuhan untuk tujuan pembangunan keselamatan dan perdamaian yang hakiki. Islam, yang dibawa Nabi Muhammad s.a.w., bukanlah agama baru, melainkan agama Tauhid yang telah lebih dulu diajarkan oleh para nabi dari Adam a.s. hingga 'Isa a.s.. Islam, bagi Musa Asy'arie, merupakan suatu penyerahan total hanya pada Allah semata, yang dengan kepasrahan total ini, energi Ilahiyah dan sifat-sifat agung-Nya akan terserap ke dalam dirinya, dan dengan cara demikian, dia akan kebebasan, ketenangan, keselamatan dan kedamaian. Kepasrahan yang tulus pada Allah adalah sumber energi dan kekuatan kreatif yang tidak pernah habis untuk mendorong kesalihan dan kebajikan. ${ }^{17}$

Islam dengan demikian lebih kental dengan ajaran cinta kasih dan perdamaian. Dengan mentransendensikan diri melalui ketundukan total dan tulus pada Allah, kejernihan hati dan pikiran manusia muslim tampak jelas dalam memandang sama semua manusia. Karena ketauhidan, manusia muslim tidak melihat keunggulan manusia dari segi ras, warna kulit, suku, bangsa, negara, kecerdasan, kekayaan, kebagusan fisik, bahasa, dan lain

${ }^{17}$ Musa Asy'arie, Dialektika Agama untuk Pembebasan Spiritual, diedit oleh Andi Dermawan, (Yogyakarta: LESFI, 2002), h. 57-58. 
sebagainya. Keunggulan manusia hanya dinilai dari integritas moralitas yang menjunjung tinggi nilai kemanusiaan, kebersamaan, dan keharmonian dengan lingkungan dan alam, sebagai buah dari ketaatan dan kecintaan pada Allah.

Islam memainkan peran fundamental, karena al-Qur'an mengajarkan manusia untuk memiliki "yang baik" dan menghindari "yang buruk", dalam penanaman dan penyebaran civic values. Civic values dalam Islam sesungguhnya sudah tercermin dalam ajarannya mengenai sistem moral (akhlaq) atau etika Islam. Etika Islam dengan sangat gamblang menunjukkan pengondisian kehidupan bermasayarakat berbasis civic values. Standar putusan "yang baik" dan "yang buruk" menurut Islam, manusia tidak sampai pada eksistensi pada dirinya sendiri dan dia bukan suatu produk dari kekuatan alam yang kemudian bergabung untuk menghasilkan kehidupan. Sebaliknya, manusia adalah suatu ciptaan Sang Kreator yang Maha Bijaksana dan Maha Pengasih. Tuhan memberi manusia kehidupan dan dengan itu juga memberi manusia kebebasan dan otoritas untuk melakukan yang baik dan melakukan yang jahat. Otoritas dan kebebasan ini diberikan pada manusia dengan tujuan dasar untuk mengujinya, mengenai bagaimana dia menggunakan otoritas dan kebebasan. Sebagai suatu bagian dari ujian ini, Tuhan juga memberikan pengetahuan dasar tentang "yang baik" dan "yang buruk" pada waktu insepsinya. Jadi, menurut Islam, setiap individu telah dianugerahi suatu standar putusan yang jelas tentang "yang baik" dan "yang buruk" oleh Tuhan. Al-Qur'an, dalam Surah as-Syam (91): 7-10 telah menyajikan pengetahuan jiwa manusia sebagai suatu bukti dari fakta bahwa manusia akan menghadapi konsekuensi-konsekuensi terpisah dari perilaku "baik"dan "buruk"nya.

Jadi, menurut etika Islam, pengetahuan tentang yang baik dan yang buruk atau dengan kata lain standar-standar membedakan yang baik dari yang buruk merupakan sebagian the sapiential sense of man (rasa kemanusiawian manusia). Etika Islam dengan sangat jelas mengedepankan rasa kemanusiawian dalam mempertimbangkan keberlangsungan dan keberlanjutan kualitas kebaikan hidup manusia, karena etika Islam setidaknya mendorong perilaku dengan konsep-konsep, yang tidak asing dengan isuisu civic values dalam kehidupan modern, di antaranya konsep-konsep seperti keadilan (justice), kesetiaan (truthfulness), kejujuran (bonesty), membantu yang 
lemah (helping the weak), kebebasan dalam masalah personal orang (freedom in one's personal matters), dan masih banyak konsep lainnya. Meskipun mungkin dalam penerapan konsep-konsep tersebut ada perbedaan, namun konsep-konsep itu sendiri tidak pernah dipersoalkan dan diterima secara universal. Untuk alasan inilah nilai-nilai etis seperti keadilan, kejujuran, bisa dipercaya, kesetiaan dan lain sebagainya secara filosofis tidak pernah dipersoalkan, dan bahkan desawa ini nilai-nilai pergaulan hidup antar manusia dengan latar ragam tradisi, budaya, nilai, agama, bahasa, kepentingan, dan lain sebagainya dalam Islam seperti ini diperkuat dan didorong dan dikenal sebagai isu-isu civic values karena ini diyakini bisa mengatas konflik antara manusia.

Bukti konkret dari makna substansial dari ajaran Islam, yang intisarinya tergambar dalam etika Islam, yang mendorong nilai-nilai kewargaan (civic values) itu tampak jelas dalam perubahan dari masyarakat 'Arab pra Islam Rasulullah Muhammad s.a.w. menjadi masyarakat 'Arab pasca Islam Rasulullah Muhammad saw.

Di Jazirah Arab sebelum kedatangan Islam, masyarakatnya dikenal dengan dengan masyarakat barbar dan jabiliyyah. Masyarakat Arab pra Islam dicirikasi dengan fenomena berikut: budaya keagamaan paganisme atau penyembahan berhala, fanatisme kesukuan Arab yang begitu dominan, pembunuhan anak perempuan karena tradisi yang memandang punya anak perempuan adalah aib dan memalukan, perbudakan, kekerasan dan pelecehan terhadap perempuan, pemusatan kekayaan pada pengusaha besar yang memonopoli pasar, dan kekuasaan yang pemegangnya ditentukan berdasarkan suku yang terkuat, dan lain sebagainya. ${ }^{18}$

Di antara warga masyarakat Arab pra Islam yang tertekan dan tersisih sebenarnya tidak menyukai tatanan masyarakatnya yang barbar dan biadab. Namun, bagaimanapun mereka tidak berdaya kecuali menunggu nasib karena dominasi dn hegemoni kekuasaan otoriter yang sedemikian kuat. Dari gambaran ini, masyarakat Arab pra Islam menunjukkan suatu tatanan masyarakat yang tidak membuka "kran" kebebasan ruang publik warganya.

\footnotetext{
${ }^{18}$ Muntoha dkk, Pemikiran dan Peradaban Islam, (Yogyakarta: LPPAI-UII Press, 1997), h. 24-29.
} 
Pada awal kedatangan Islam pun tidak terlepas dari kekuatan otoriter ini. ${ }^{19}$ Misi peradaban Muhammad SAW. dan pengikutnya, yang menggambarkan menggeliatnya ruang publik, mendapat perlawanan yang luar biasa karena dianggap sebagai mengganggu singgasana status quo masyarakat Arab. Namun, ketika Masyarakat Arab berada dalam penguasaan dan pengelolaan Islam, terjadi perubahan-perubahan revolusioner, dari budaya keagamaan paganisme kepada Tauhid, dari fanatisme kesukuan yang keterlaluan kepada persaudaraan antar sesama manusia tanpa melihat perbedaan agama, ras, etnis, maupun warna kulit, dari pelecehan perempuan dan kebebasan seks kepada penghargaan martabat wanita dan sakralisasi seks ke dalam institusi pernikahan, dari pembunuhan dan perampasan kepada perdamaian dan persamaan hak, dan dari kapitalisme individualistik-egoistik kepada sosialisme religius-demokratis. Perubahan-perubahan ini berjalan cepat dan mudah; ha ini terjadi bukan karena determinasi dan hegemoni kekuasaan semata, melainkan secara substansial karena sejak lama warga masyarakat Arab menunggu-nunggu tatanan masyarakat yang beradab, rasional dan manusiawi. Dengan kata lain, keberhasilan reformasi sosial-politik masyarakat Arab oleh Islam tersebut sangat ditentukan oleh dukungan arus bawah dari segenap warga sipil yang menginginkan kemerdekaan dan perlakuan adil dan manusiawi, dan hal ini bertemu dengan visi dan misi Islam.

Dalam masyarakat Arab pra-Islam bisa ditemukan praktek-praktek kehidupan sosial yang dipandangnya tidak rasional dan bertentangan dengan nilai-nilai kemanusiaan, di antara mereka adalah paganisme atau penyembahan patung-patung bikinan manusia sendiri, legitimasi perampokan sebagai mata pencaharian yang sah secara sosial, pembunuhan anak-anak perempuan, pergaulan bebas dan sistem perkawinan yang memandang poligami dan poliandri sekaligus diperbolehkan secara bebas, perbudakan, monopoli

\footnotetext{
${ }^{19}$ Tekanan otoriter masyarakat Arab Quraish terhadap Nabi demikian kuatnya sehingga Nabi terpaksa hijrah ke Abbyssinia samapi dua kali. Tekanan ini pula yang telah membungkam keberanian rakyat jelata Arab untuk mengadakan perubahan sosial dan peradaban. Menurut Yoseph Hell, "perlawanan pemuka-pemuka masyarakat musyrik Quraish bukanlah sematamata karena penolakannya terhadap ajaran Tauhid Islam yang dibawa Muhammad, tetapi justru karena ajaran Islam itu menghendaki perombakan sosial dan politik yang mengancam posisi mereka." Inilah sebab mengapa tekanan otoriter itu terjadi. Lihat, K. Ali, Sejarah Islam dari Awal hingga Runtubnya Dinasti Usmani (Tarikh Pramodern), terj. Ghufron A. Mas'adi, (Jakarta: PT RajaGrafindo Persada, 1996), h. 32-35.
} 
perdagangan oleh suku-suku terkuat, persaingan dan sistem dominasi antar suku, ketidakadilan perlakuan hukum, dan lain-lainnya. Nabi Muhammad s.a.w., dengan Islam yang mengusung persamaan, kesetaraan, kebersamaan, dan keadilan, datang sebagai utusan Allah menentang fenomena-fenomena sosial yang ada dalam masyarakat 'Arab waktu itu, dan diakhir misinya, kehidupan sosial masyarakat 'Arab berubah total dengan wajah baru yang humanis dan berkeadilan.

Nabi memulai dengan memberangus tradisi paganisme yang tidak rasional, cenderung khurafat dan mengubahnya menjadi tradisi tauhid, penyembahan satu Tuhan, Allah, yang diyakini sebagai asal-usul, penguasa, pemelihara, dan tempat kembali dari semua kehidupan ini. Dengan menempatkan Allah sebagai tempat bersandar dan pengembalian segala urusan manusia, manusia dibangunkan ke dalam kesadaran bahwa hubungan antar manusia tidak bisa didasarkan pada iklim dan sistem superioritas dan dominasi. Tidak ada suku atau kelompok tertentu berkuasa secara otoriter atas kelompok lain, karena dengan kembali kepada kesadaran tauhid bahwa hanya Tuhanlah yang Maha Kuasa. Secara sosial setiap manusia dinilai sama, tidak ada manusia yang lebih unggul dari manusia lainnya. Dalam filsafat sosial Islam, sebagaimana terefleksi dalam pikiranpikiran religius Nabi Muhammad saw., ketinggian kualitas manusia terletak pada nilai moralitas yang dimiliki dan diperjuangkannya - dalam bahasa agama sering diungkapkan dengan "Orang yang paling mulia adalah orang yang paling bertaqwa kepada Tuhan." ${ }^{20}$

Kebiasaan merampas dan merampok harta benda orang lain dari orang-orang Arab Badui direspon nabi sebagai tindakan asosial karena mendapatkan kekayaan secara jalan pintas tetapi memaksa dengan merugikan, menganiaya bahkan membunuh orang lain yang juga ingin memiliki harta benda. Nabi menggantinya dengan tradisi pencarian kekayaan secara material dengan cara-cara yang halal, suatu cara memperoleh kebutuhan hidup di dunia dengan tidak merugikan dan tidak merampas kepemilikan orang lain.

Nabi dengan keras mengutuk pembunuhan anak perempuan oleh orang tuanya sendiri dengan alasan kehormatan keluarga dan pengorbanan

${ }^{20}$ Q.S. Al-Hujurãt (49): 13. 
anak perempuan oleh masyarakatnya demi stabilitas sosial dan terhindarnya masyarakat dari mara bahaya. Perempuan dan laki-laki dipandang sama mulianya dalam Islam, mereka memiliki hak dan perlakuan yang sama secara politis, sosial dan kultural, keduanya hanya berbeda secara biologis. Menanggapi pergaulan bebas antara laki-laki dan perempuan, dan merespon praktek poligami dan poliandri sekaligus, Nabi membangun etika pergaulan dan batas-batasnya dan melembagakan perkawinan sebagai ikatan suci secara sosial. Poligami dibolehkan dengan syarat-syarat tertentu seperti mampu secara ekonomi, berlaku adil, dan terdapat unsur kerelaan antar isteri-isteri.

Nabi juga menolak praktek perbudakan di mana manusia dibeli dan dimiliki oleh manusia lainnya layaknya memiliki dan memperlakukan benda. Perbudakan adalah suatu pelanggaran hak asasi manusia untuk diperlakukan sama secara sosial dan secara manusiawi. Dalam kehidupannya, Nabi banyak melakukan pembebasan budak, salah satu di antaranya adalah Muazin pertama dalam Islam yaitu Bilal bin Rabah. Nabi mengajarkan persamaan antar manusia meskipun mereka berbeda warna kulit, agama, bahasa, ras, dan keturunan.

Ekonomi kapitalistik yang tidak menyantuni kaum lemah sebagaimana tercermin dalam praktek monopoli perdagangan oleh suku-suku terkuat dan dominan dirombak ke dalam sistem ekonomi yang mempertimbangan kemakmuran bersama antar manusia, terutama bagaimana memperjuangkan kaum lemah memperoleh kemungkinan-kemungkinan dan fasilitas-fasilitas sosial dalam mengembangkan diri dan menyejahterakan diri. Sadaqah, zakat, dan infaq dianjurkan sebagai bagian integral dari etika perolehan ekonomi. Sadaqah, zakat, dan infaq ini adalah sebagai salah satu perwujudan dari pemberdayaan kaum lemah.

Fenomena yang menonjol dalam kehidupan masyarakat Arab pra Islam adalah persaingan antar suku dan saling mendominasi satu sama lain meskipun harus melalui perang. Kebiasaan ini diubah Nabi ke dalam semangat persaudaraan. Persaudaraan atas dasar nilai-nilai dasar dan universal manusia dan kemanusiaan dijunjung tinggi mengatasi perbedaanperbedaaan suku dan lain sebagainya.

Ketidakadilan hukum bisa ditemukan pada fakta pembunuhan orang dari suku tertentu oleh orang dari suku tertentu. Hukum membenarkan 
atau menganggap impas, apabila salah satu anggota suku yang membunuh diserahkan untuk dibunuh, meskipun yang diserahkan tidak harus pembunuhnya. Nabi memandang ini sebagai hukum yang tidak adil. Islam mengajarkan tentang qishâsh, nyawa dibalas dengan nyawa, yakni pembunuh harus dihukum mati sebagai keadilan atas nyawa seseorang yang telah dibunuh.

Setelah kehadiran ajaran Islam yang dbawa Nabi Muhammad s.a.w., kehidupan sosial masyarakat 'Arab berubah total dari kehidupan yang tidak manusiawi, tidak berkeadaban, dan tidak berkeadilan, yang dalam istilah Islam sering dikenal dengan jahiliyah, menjadi kehidupan yang manusiawi, berkeadaban, dan bereadilan.

Keberhasilan Rasulullah Muhammad s.a.w. dalam mengubah masyarakat yang tidak manusiawi, tidak berkeadaban, dan tidak berkeadilan menjadi yang manusiawi, berkeadaban, dan berkeadilan merupakan bukti konkret historis bahwa Islam memberikan potret pembangunan masyarakat yang memanusiakan manusia, suatu masyarakat yang mencoba memberi ruang keadilan yang berkesetaraan bagi setiap warga masyarakat, dan ini di era dewasa ini sering disebut sebagai semangat dari civil society.

Civil society bisa dicirikan oleh ruang publik yang bebas, demokratis, pluralis, toleran, keadilan sosial, dan berkeadapan. ${ }^{21}$ Syafi'i Ma'arif menggarisbawahi ada empat ciri civil society, yaitu justice-oriented, egalitarianisme, toleransi dan keterbukaan. ${ }^{22}$ Dari ciri-ciri ini dapat disimpulkan bahwa tujuan utama dari civil society adalah penjunjungan tinggi nilai-nilai humanitas atau pemanusiaan manusia.

Ciri-ciri itu memang juga melekat pada model masyarakat yang banyak diperbincangkan oleh kaum muslim, yakni Masyarakat Madani. Tujuan utama dan dasarnya pun sama yakni pemanusiaan manusia, namun belum tentu sama paradigmanya.

Sepakat dengan Nurcholish Madjid bahwa jauh sebelum Barat mengenal dan mempraktikkan civil society, Nabi Muhammad SAW. sudah menerapkannya di Madinah. Nabi Muhammad SAW membangun masya-

${ }^{21}$ Ubaidillah dkk, Pendidikan Kewargaan (Civic Education) Demokrasi, HAM, \& Masyarakat Madani, (Jakarta: IAIN Syarif Hidayatullah Press, 2000), h. 147

${ }^{22}$ Syafi'i Ma'arif, "Universalisme Nilai-nilai Politik Islam Menuju Masyarakat Madani," Profetika Jurnal Studi Islam, Vol. I, No. 2 Juli 1999: h. 172. 
rakat Madinah berdasarkan cinta kasih dan semangat saling mendukung. Rasa kebersamaan saling menjaga dan melindungi merupakan dasar bersama yang dimiliki oleh masyarakat Madinah baik orang tua, orang muda, kaya dan miskin, dan perbedaan-perbedaan sosial lainnya. ${ }^{23}$ Nilai-nilai etis kemasyarakatan ini terlihat dengan gamblang dalam Piagam Madinah (Mitsaq al-Madinab). Menurut Aqil Siradj, Piagam Madinah itu memuat 47 pasal, ${ }^{24}$ tetapi sebenarnya, dalam naskah aslinya tidak ada penomoran. Penomoran dilakukan untuk mempermudah menandai. ${ }^{25}$ Berikut ini salah satu versi terjemah dari naskah Piagam Madinah:

1. Surat Perjanjian (kitab) ini dibuat oleh Muhammad dalam kedudukan sebagai Nabi; antara para Mu'min, dan kaum Muslimin dari kalangan Quraisy dan Yatsrib serta yang mengikuti mereka dan menyusul mereka dan berjuang bersama-sama mereka; (menyatakan) bahwa mereka adalah satu umat, di luar golongan manusia lain.

2. Kaum Muhajirin dari kalangan Quraisy boleh meneruskan adat kebiasaan baik yang berlaku ('ala rib'atibim/riba'atibim) di kalangan mereka, (yaitu) bersama-sama menerima atau membayar tebusan darah (yata'aqalun) antara sesama mereka dan mereka menebus tawanan mereka sendiri dengan cara yang baik dan adil di antara sesama orang-orang beriman.

3. Begitu juga Banu 'Auf boleh meneruskan adat kebiasaan baik mereka yang berlaku, (yaitu) bersama-sama membayar tebusan darah seperti biasa. Begitu pula setiap golongan harus menebus tawanan mereka sendiri dengan cara yang baik dan adil di antara sesama orang-orang beriman. (Kemudian disebutnya setiap suku/batn Anshar itu serta keluarga setiap puak; Banul-Harits, Banu Sa’ida, Banu Jusyam, Banu-Najjar, Banu 'Amr bin 'Auf dan Banu-Nabit. Selanjutnya disebutkan):

${ }^{23}$ Akram Diya' al-'Umari, Madinah Society at the Time of the Prophet, trans. Huda Khattab, (USA: The International Institute of Islamic Thought, 1995), h. 79.

${ }^{24}$ Lihat Aqil Siradj, Terjemahan Teks Tekes Asli Piagam Madinab (Internet "Warung Silah", 5-9-1999), h. 4, Bandingkan dengan Munawir Syadzali, Islam dan Tata Negara, Ajaran, Sejarah, dan Pemikiran, (Jakarta: UI Press, 1993), h. 10-15.

${ }^{25}$ http://ahmadhaes.wordpress.com/2009/02/23/piagam-madinah-konstitusi-modern-di-zaman-jahiliyah/, diakses 15 Nopember 2010. 
4. Bahwa orang-orang yang beriman tidak boleh membiarkan seseorang yang menanggung beban hidup dan utang yang berat di antara sesama mereka. Mereka harus dibantu dengan cara yang baik dalam membayar tebusan tawanan atau membayar diat.

5. Bahwa seseorang yang beriman tidak boleh mengikat janji (besekutu; bersekongkol) untuk menghadapi mu'min lainnya.

6. Bahwa orang-orang yang beriman dan bertakwa harus melawan orang yang melakukan kejahatan di antara mereka sendiri, atau orang yang suka melakukan perbuatan aniaya, kejahatan, permusuhan atau berbuat kerusakan di antara orang-orang beriman sendiri, dan mereka semua harus sama-sama melawannya walaupun terhadap anak sendiri.

7. Bahwa seseorang yang beriman tidak boleh membunuh sesama mu'min demi membela orang kafir, dan tidak boleh membantu orang kafir untuk melawan mu'mim.

8. Bahwa jaminan Allah itu satu (yaitu): Dia melindungi yang lemah di antara mereka.

9. Bahwa orang-orang beriman itu hendaknya saling tolong-menolong satu sama lain.

10. Bahwa barangsiapa dari kalangan Yahudi yang menjadi pengikut kita, ia berhak mendapat pertolongan dan persamaan; tidak boleh menganiaya atau memusuhi mereka.

11. Bahwa orang-orang beriman bersatu dalam persetujuan damai; tidak dibenarkan seorang mu'min mengadakan perdamaian sendiri dengan meninggalkan mu'min lainnya dalam keadaan perang di jalan Allah. Mereka harus sama dan adil.

12. Bahwa setiap orang yang berperang bersama kita satu sama lain harus saling bergiliran.

13. Bahwa orang-orang beriman itu harus saling membela terhadap sesamanya yang telah tewas di jalan Allah.

14. Bahwa orang-orang yang beriman dan bertakwa hendaknya menempatkan diri dalam pimpinan yang baik dan lurus.

15. Bahwa siapa pun tidak dibolehkan melindungi harta-benda atau jiwa orang Quraisy dan tidak boleh merintangi orang beriman. 
16. Bahwa barang siapa membunuh orang beriman yang tidak bersalah dengan cukup bukti, maka ia harus mendapat balasan yang setimpal, kecuali bila keluarga si terbunuh sukarela (menerima tebusan).

17. Bahwa orang-orang yang beriman harus menentangnya semua dan tidak dibenarkan mereka hanya tinggal diam.

18. Bahwa seseorang yang beriman yang telah mengakui isi piagam ini dan beriman kepada Allah dan hari kemudian, tidak dibenarkan menolong pelaku kejahatan atau membelanya, dan bahwa barangsiapa yang menolongnya atau melindunginya, ia akan mendapat kutukan dan murka Allah pada hari kiamat, dan tak ada tebusan yang dapat diterima.

19. Bahwa bila di antara kamu timbul perselisihan tentang sesuatu masalah yang bagaimana pun, maka selesaikan dengan ajaran Allah melalui Muhammad - 'alaihi-shalatu wa salam.

20. Bahwa orang-orang Yahudi harus mengeluarkan dana bersama orang-orang beriman selama mereka masih dalam keadaan perang.

21. Bahwa orang-orang Yahudi Banu 'Auf adalah satu umat dengan orang-orang beriman. Orang-orang Yahudi hendaknya berpegang pada agama mereka, dan orang-orang Islam pun hendaknya berpegang pada agama mereka pula, termasuk pengikut-pengikut mereka dan diri mereka sendiri, kecuali orang yang melakukan perbuatan aniaya dan durhaka. Orang semacam ini hanyalah akan menghancurkan dirinya dan keluarganya sendiri.

22. Bahwa terhadap orang-orang Yahudi Banu-Najjar, Yahudi BanulHa-rits, Yahudi Banu Sa’ida, Yahudi Banu-Jusyam, Yahudi Banu Aus, Yahudi Banu Tsa'labah, Jafnah dan Banu Syuthaibah, berlaku sama seperti terhadap mereka sendiri.

23. Bahwa tiada seorang dari mereka itu boleh keluar kecuali dengan ijin Muhammad saw.

24. Bahwa seseorang tidak boleh dirintangi menuntut haknya yang diakui; dan barangsiapa yang diserang, ia dan keluarganya harus membela diri, kecuali jika ia menganiaya. Ini merupakan ketentuan Allah.

25. Bahwa orang-orang Yahudi berkewajiban menanggung nafkah mereka sendiri dan kaum Muslimin pun berkewajiban menanggung 
nafkah mereka sendiri pula. Antara mereka harus ada tolongmenolong dalam menghadapi orang yang hendak menyerang pihak yang mengadakan piagam perjanjian ini.

26. Bahwa mereka sama-sama berkewajiban, saling nasihat-menasihati dan saling berbuat kebaikan dan menjauhi segala perbuatan dosa.

27. Bahwa seseorang tidak dibenarkan melakukan perbuatan salah terhadap sekutunya, dan bahwa yang harus ditolong ialah yang teraniaya.

28. Bahwa orang-orang Yahudi berkewajiban mengeluarkan belanja bersama orang-orang beriman selama masih dalam keadaan perang.

29. Bahwa kota Yatsrib adalah kota yang dihormati bagi orang yang melakukan perjanjian ini (menjadi kota perjanjian).

30. Bahwa tetangga itu seperti diri sendiri, tidak boleh diganggu dan diperlakukan secara jahat.

31. Bahwa suatu tempat yang dihormati tidak boleh didiami orang tanpa ijin penduduknya.

32. Bahwa bila di antara orang-orang yang mengakui perjanjian ini terjadi suatu perselisihan yang dikhawatirkan akan menimbulkan kerusakan, maka rujukannya adalah ajaran Allah melalui Muhammad saw, dan bahwa Allah mendukung orang yang teguh dan setia memegang perjanjian ini.

33. Bahwa melindungi orang-orang Quraisy (yang kafir) atau menolong mereka tidak dibenarkan.

34. Bahwa antara mereka harus saling membantu melawan orang yang hendak menyerang Yatsrib ini. Tapi bila telah diajak berdamai maka sambutlah ajakan perdamaian itu.

35. Bahwa apabila mereka diajak berdamai, maka orang-orang yang beriman wajib menyambutnya, kecuali kepada orang yang memerangi agama. Bagi setiap orang, dari pihaknya sendiri mempunyai bagiannya masing-masing.

36. Bahwa orang-orang Yahudi Aus, baik diri mereka sendiri atau pengikut-pengikut mereka mempunyai kewajiban seperti mereka yang sudah menyetujui naskah perjanjian ini dengan segala kewajiban sepenuhnya dari mereka yang menyetujui naskah perjanjian ini. 
37. Bahwa kebaikan itu tidak sama dengan kejahatan dan bagi orang yang melakukannya hanya akan memikul sendiri akibatnya. Dan bahwa Allah bersama pihak yang benar dan patuh menjalankan isi perjanjian ini.

38. Bahwa orang tidak boleh melanggar isi perjanjian ini, kecuali bila ia orang yang zhalim dan/atau jahat.

39. Bahwa barangsiapa yang keluar atau tinggal dalam kota Madinah ini, keselamatannya tetap terjamin, kecuali orang yang berbuat zhalim dan melakukan kejahatan.

40. Allah pasti melindungi orang yang baik/bertakwa, dan Muhammad adalah Rasul Allah (yang mengemban tugas melaksanakan hukum Allah). ${ }^{26}$

Piagam Madinah dalam pandangan Syafi'i Ma'arif adalah bahwa kita dikenalkan kepada ide-ide politik yang sangat revolusioner, etis, dan anggun. Bukan saja untuk masa itu, bahkan gaungnya masih terasa bermakna pada dekade terakhir abad ke-20. Piagam ini jelas mempunyai tujuan strategis bagi terciptanya keserasian politik dengan mengembangkan toleransi sosioreligius dan budaya seluas-luasnya. Piagam ini saya katakan revolusioner karena antara lain semua penduduk Madinah bersama pendatang, yaitu kaum muhajirin dari Mekah dikategorikan sebagai satu umat berhadapan dengan manusia lain. ${ }^{27}$

Mengenai Piagam Madinah, Muhammad Husain Haikal menyatakan, inilah dokumen politik yang telah diletakkan Muhammad saw. sejak lebih dari sepuluh abad yang lalu dan yang telah menetapkan adanya adanya kebebasan beragama, kebebasan menyatakan pendapat; tentang keselamatan harta-benda dan larangan orang melakukan kejahatan. Ia telah membukakan pintu baru dalam kehidupan politik dan peradaban dunia masa itu. Apabila dalam penandatanganan dokumen ini orang Yahudi Banu Quraiza, Banu'n-Nadzir dan Banu Qainuqa' tidak ikut serta, namun tidak selang lama sesudah itu mereka pun mengadakan perjanjian yang serupa dengan Nabi. Nurcholis Madjid berpendapat bahwa bunyi naskah Konstitusi (Piagam madinah) itu sangat menarik; ia memuat pokok-pokok pikiran

${ }^{26} \mathrm{http}: / /$ ahmadhaes.wordpress.com.

${ }^{27}$ Seperti dikutip dalam http://ahmadhaes.wordpress.com. 
yang dari sudut tinjauan modern pun mengagumkan. Dalam Konstitusi itulah untuk pertama kalinya dirumuskan ide-ide yang kini menjadi pandangan hidup modern di dunia. ${ }^{28}$

Menurut Pulungan, yang secara substansial nilai-nilai kontrak sosial yang terkandung dalam Piagam Madinah dapat dirangkum ke dalam 14 prinsip berikut: 1. Prinsip Umat, 2. Prinsip Persatuan dan Persaudaraan, 3. Prinsip Persamaan, 4. Prinsip Kebebasan, 5. Prinsip Hubungan Antar Pemeluk Agama, 6. Prinsip Tolong-menolong dan Membela yang Teraniaya, 7. Prinsip Pergaulan sosial, 8. Prinsip Perdamaian, 9. Prinsip Pertahanan, 10. Prinsip Musyawarah, 11. Prinsip Keadilan, 12. Prinsip Supremasi Hukum, 13. Prinsip Kepemimpinan, 14. Prinsip Ketaqwaan, Amar Ma'ruf dan Nahi Mungkar. ${ }^{29}$

Pertama kali istilah Masyarakat Madani disebut oleh Anwar Ibrahim dalam ceramahnya pada Simposium Nasional dalam rangka Forum Ilmiah pada acara Festival Istiqlal, 26 September 1995. Kemudian istilah ini dipopulerkan oleh Naquib al-Attas, seorang ahli sejarah dan peradaban Islam dari Malaysia dan salah satu pendiri Institute for Islamic Thought and Civilization (ISTAC). ${ }^{30}$ Istilah ini di Indonesia lalu menjadi wacana yang hangat, hingga dalam perkembangannya banyak yang menyamakan antara civil society dan Masyarakat Madani. Apabila mengkaji Masyarakat Madani dari konsep-konsep masyarakat sipil Barat berkencenderungan akan menyamakannya dengan civil society.

Berbicara tentang Masyarakat Madani semestinya berpijak pada sejarah hidup Nabi sendiri, sebagaimana tercermin dalam kehidupan kemasyarakatan di Madinah. Dari situ pula akan ditemukan paradigma pemikiran sosial-kemasyarakatan yang khas melekat pada Masyarakat Madinah yang membedakannya dengan civil society Barat.

Jika dianalisis dari paradigma kultur mana kedua masyarakat itu lahir dan tumbuh, perbedaan asasiah antara Masyarakat Madani dan civil society akan tampak. Jika kembali kepada kultur para filosof sosial Barat abad

\footnotetext{
${ }^{28}$ Seperti dikutip dalam http:// ahmadhaes.wordpress.com.

${ }^{29}$ J. Suyuthi Pulungan, Prinsip-prinsip Pemerintahan dalam Piagam Madinah, Jakarta: Lembaga Studi Islam dan Kemasyarakatan, 1996), h. 121.

${ }^{30}$ Ubaidilah dkk, Pendidikan Kewargaan..., h. 140.
} 
ketujuh belas di mana wacana civil society itu mulai digulirkan, maka civil society di Barat lahir sebagai buah modernitas yang mengambil akarnya pada gerakan budaya Renaissance. Budaya ini merupakan gerakan yang memarginalkan gagasan tentang Tuhan. Buah masyarakat dari gerakan budaya semacam ini adalah masyarakat sekuler, yang menurut Clavel, di dalamnya posisi Tuhan telah menjadi gagasan yang tertindas sejak lebih dari tiga abad yang lalu. ${ }^{31}$ Humanisme yang dikembangkan kultur Renaissance adalah humanisme liberal di mana kebebasan individual-kapitalistik merupakan produknya yang paling menonjol. Humanisme ini dengan sengaja "memenggal" pondasi moral-transendental yang menurut R.D. Laing, seperti dikutib Camilleri, telah menggiring masyarakat sekuler modern ke dalam sebuah an ontological insecurity (ketidakamanan ontologis). ${ }^{32}$

\section{Penutup}

Masyarakat Madani dalam praktek hidup Nabi bukan berangkat dari humanisme liberal, melainkan humanisme transendental, yakni gerakan kultur pemanusiaan manusia yang didasarkan pada landasan etis dan moral transenden, di mana Tuhan menjadi sumber elan vital setiap manusia untuk memanusiakan sesamanya. Produk dari humanisme ini bukan kebebasan individual-kapitalistik tetapi kebebasan individual-transendental. Dalam humanisme liberal, peran individual-kapitalistiknya sangat menonjol dalam masyarakat sipil modern di Barat sekarang ini, sehingga masalah keadilan sosial dan ekonomi menjadi tanda tanya besar. Karena dalam humanisme liberal dan demokrasi liberal, setiap individu dibenarkan memperoleh kekayaan tanpa batas. Jika demikian bisa muncul suatu otoriterianisme baru dari masyarakat sipil. Kalau dulu otoriterianisme ada pada negara, dalam masyarakat modern muncul otoriterianisme sipil yang dimotori individuindividu yang juga kapitalis-kapitalis kelas kakap. Dalam pengkondisian seperti ini, kecenderungan monopoli pasar menjadi sangat mencolok. Nilai etis moral mana yang mampu mengerem kecenderungan seperti ini jika

${ }^{31}$ Seperti dinukil Michael Aeschliman, "The Real Nietzsche" dalam The World an I, January, 1990: h. 846.

${ }^{32}$ Joseph A. Camilleri, Civilization in Crisis: Human Prospects in a Changing World, (Cambridge: Cambridge University Press, 1976), h. 36. 
bukan nilai-nilai etis transendental yang diberikan agama. Hukum dan segala bentuk peraturan bisa dibuat manusia, tetapi siapa yang bisa menjamin orang untuk tidak melanggar hukum dan peratuaran-peraturan itu selain nilainilai moral yang tertanam melalui penghayatan keagamaan secara individual.

Itulah yang menjadi dasar dari humanisme transendental yang merupakan paradigma dari Masyarakat Madani. Dalam humanisme ini, ketamakan moral-transendentallah yang dibolehkan tanpa batas, bukan ketamakan ekonomi, kekuasaan dan sebagainya, karena ketamakanketamakan ini pasti punya konsekuensi melukai orang lain. Sementara ketamakan moral-transendental tidak memiliki peluang sedikitpun untuk melukai orang lain. Moralitas transendental ini menurut Nurcholish Madjid terrefleksikan dalam Taqwa kepada Allah Ta'ala, dan inilah yang menjadi asas yang paling dasar dari Masyarakat Madani, seperti katanya berikut ini:

Taqwa kepada Allah dalam arti semangat ketuhanan yang Maha Esa, yang dalam peristilahan kitab suci juga disebut semangat Rabbaniyyah (Q.S. Ali Imran: 79) atau Ribbiyyah (Q.S. Ali Imran: 146). Inilah bablun Min Allah, tali hubungan dengan Allah, dimensi vertikal hidup manusia, salah satu jaminan untuk manusia agar tidak jatuh hina dan nista. Semangat Rabbaniyyah atau Ribbiyyah itu, jika cukup tulus dan sejati akan memancarkan semangat peri kemanusiaan, yaitu semangat insaniyyah atau basyariyyah, dimensi horisontal hidup manusia, hablun min al-nas, kemudian pada urutannya, semangat peri kemanusiaan itu sendiri memancar dalam berbagai bentuk hubungan pergaulan sesama manusia penuh budi luhur. Maka tak heran jika Nabi dalam sebuah hadisnya menegaskan bahwa intisari tugas suci beliau adalah untuk "menyempurnakan berbagai keluhuran budi," masyarakat berbudi luhur atau berakhlak mulia itulah masyarakat berperadaban, masyarakat madani. ${ }^{33}[$ ]

${ }^{33}$ Nurcholis Madjid, "Menuju Masyarakat Madani,” dalam Ulumul Qur'an No. 2/VII/ 1996), h. 52. 


\section{DAFTAR PUSTAKA}

al-'Umari, Akram Diya'. (1995). Madinah Society at the Time of the Prophet, trans. Huda Khattab. USA: The International Institute of Islamic Thought.

Aeschliman, Michael, "The Real Nietzsche” dalam The World and I, January, 1990.

Ahimsa-Putra, Heddy Shri, "Gender dan Pemaknaannya: Sebuah Ulasan Singkat", Makalah Disampaikan dalam Workshop "Sensivitas Gender dalam Manajemen”, PSW IAIN Sunan Kalijaga, 28 September 2000 .

Ali, A. Mukti, (1992). "Ilmu Perbandingan Agama, Dialog, Dakwah, dan Misi" dalam Burhanuddin Daja dan Herman Leonard Beck (eds.), Ilmu Perbandingan Agama di Indonesia dan Belanda. Jakarta: INIS.

Ali, K., (1996). Sejarah Islam dari Awal hingga Runtubnya Dinasti Usmani (Tarikh Pramodern), terj. Ghufron A. Mas'adi. Jakarta: PT RajaGrafindo Persada.

Asy'arie, Musa, (2002). Dialektika Agama untuk Pembebasan Spiritual. Yogyakarta: LESFI.

Baso, Ahmad, (2000). Arkeologi Civil Society. Jakarta: Data Pribadi.

Berger, Peter L. dan Luckmann, Thomas, (1966). The Social Construction of Reality, a Treatise in The Sociology of Knowledge. New York: Double Day \& Company.

Berger, Peter L., (1969). The Secred Canopy: Elements of a Sociological Theory of Religion. New York: Anchors Books.

Camilleri, Joseph A., (1976). Civilization in Crisis: Human Prospects in a Changing World. Cambridge: Cambridge University Press.

Cohen, Jean L.and Arato, Andrew, (1992). Civil Society and Political Theory. Cambridge: The Mit Press. 
Daja, Burhanuddin dan Beck, Herman Leonard (eds.), (1992). Ilmu Perbandingan Agama di Indonesia dan Belanda. Jakarta: INIS.

Ellacuria, Ignacio, "What is the Point of Philosophy", Philosophy and Theology, vol 10 No. 1, 1997.

Fakih, Mansour, (1999). Analisis Gender dan Transformasi Sosial. Yogyakarta: Pustaka Pelajar.

Hansfink, (1981). Social Philosophy. London and New York: Methuen \& Co. Ltd.

Ma'arif, Syafi'i, "Universalisme Nilai-nilai Politik Islam menuju Masyarakat Madani," Profetika Jurnal Studi Islam, vol. I, No. 2 Juli 1999.

Machasin, "Respon Pesantren terhadap Civic Values, makalah dipresentasikan dalam Public Hearing Pengembangan Pesantren, Hotel Sahid Yogyakarta, 31Mei -1 Juni 2005.

Madjid, Nurcholis, "Menuju Masyarakat Madani," dalam Ulumul Qur'an No. 2/VII/1996.

Munawar-Rachman, Budi, (2001). Islam Pluralis Wacana Kesetaraan Kaum Beriman. Jakarta: Paramadina.

Muntoha dkk, (1997). Pemikiran dan Peradaban Islam. Yogyakarta: LPPAIUII Press.

Murray, John Courtney, (1960). We Hold These Truth. New York: Sheed \& Ward.

Pulungan, J. Suyuthi, (1996). Prinsip-prinsip Pemerintahan dalam Piagam Madinah. Jakarta: Lembaga Studi Islam dan Kemasyarakatan, 1996.

Roswantoro, Alim dan Sodik, Mochamad, (2008). Nilai-nilai Masyarakat Madani dalam Pemberdayaan Ekonomi. Yogyakarta: Puskadiabuma dan The Asia Foundation.

Roswantoro, Alim, "Civic Values: Membangun Visi Warga dan Kewargaan Menuju Masyarakat Madani, Perspektif Filsafat Sosial”, Jurnal 
Pemikiran Filsafat dan Pemikiran Keislaman Refleksi, vol. 5 No. 2 Juli 2005.

Ruhaini Dz., Siti, (2002). "Pengantar", dalam Islam dan Konstruksi Seksualitas, Yogyakarta: PSW IAIN- The Ford Foundation-Pustaka Pelajar.

Syadzali, Munawir, (1993). Islam dan Tata Negara, Ajaran, Sejarah, dan Pemikiran. Jakarta: UI Press.

Tjahjono, Subur dan Prihadiyoko, Imam, "M. Syafi'i dan Obsesi Pluralisme" hasil wawancara dengan M. Syafi'i Anwar, Direktur Eksekutif International Centre for Islam and Pluralism (ICIP), Harian Kompas, Sabtu, 30 Juli 2005.

Ubaidillah dkk, (2000). Pendidikan Kewargaan (Civic Education) Demokrasi, HAM, \& Masyarakat Madani. Jakarta: IAIN Syarif Hidayatullah Press. 